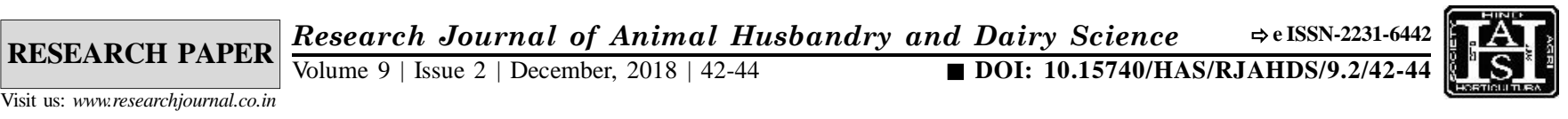

\title{
Effect of mineral mixture feeding on milk yield in buffalo
}

\author{
P.K. Madke, Devendra Pal, Satya Prakash and Anant Kumar
}

\begin{abstract}
A field study was conducted in Ghaziabad district to observe the effect of mineral mixture feeding on milk yield in Buffalo. Animals were selected randomly from 5 villages of Ghaziabad (U.P.) (Muradnagar, Noorpur, Kanoja, Kusalia, and Badka). 20 Buffaloes were selected in their $2^{\text {nd }}$ and $3^{\text {rd }}$ stage of lactation and divided into two groups of 10 animals each. First group (T) was fed with $60 \mathrm{~g}$ mineral mixture daily till 90 days of lactation. Other group (C) of 10 animals were not fed additional mineral mixture, which is farmers practice in that particular area. The farmers were not fed scientific method of feeding. They could not added proper quantity of mineral mixture in balance ration. To keeping in mind a trial was conducted in Ghaziabad district since 2016-17 (2017-18). Milk yield of these animals was recorded by their owners and these values were averaged for fortnightly interval. Milk production parameters like average daily milk yield, peak yield and total milk yield were compared between treatment and control groups. It was observed that average daily milk yield, peak yield and total milk yield were found significantly $(\mathrm{P}<0.05)$ higher by 11.04, 12.37 and 11.61 per cent in mineral mixture fed group than control group. On the basis of this, it is recommended that continuous feeding of mineral mixture bettered performance of milk yield in buffaloes.
\end{abstract}

KEY WORDS : Mineral mixture, Feeding on milk yield, Buffalo

How TO CITE THIS PAPER : Madke, P.K., Pal, Devendra, Prakash, Satya and Kumar, Anant (2018). Effect of mineral mixture feeding on milk yield in buffalo. Res. J. Animal Hus. \& Dairy Sci., 9(2) : $42-44$ : DOI: 10.15740/HAS/RJAHDS/9.2/42-44. Copyright@ 2018: Hind Agri-Horticultural Society.

\section{INTRODUCTION}

India is the first in milk producing country in the world accounting for 18.5 per cent of world milk production and achieving an annual output of 146.3 million tones during 2014-15, with a growth of 6.26 per cent. However, in other aspect present level of buffaloes milk in Western U.P. is very low, under production is mainly result of involuntary culling due to poor body condition, low fertility and some health issue, eventually it affects profitability from the animals. The balanced nutrition is very essential for keeping animal body in good condition and renders them to maintain their optimum production out of all

Address for correspondence :

P.K. Madke, Krishi Vigyan Kendra, Muradnagar, Ghaziabad (U.P.) India

Associated Authors' :

Devendra Pal, Satya Prakash and Anant Kumar, Sardar Vallabhbhai Patel University of Agriculture and Technology, Meerut (U.P.) India nutrients minerals and vitamin play a crucial role in metabolism, location, reproduction and even for microbial fermentation in rumen (Bhannderi et al., 2014).

Most of the animals in developing countries including India are fed on agriculture by products and low quality crop residues, which have got low inherent, low nutritive value and digestibility. High producing buffaloes in early lactation do not consume sufficient dry matter to support maximum production of milk (Goff and Horst, 1997). Demand for energy is very high during early stage of lactation but supply is not commensurate with demand due physiological stage or limited intake may affects production potential of animal in the whole lactation length (Sirohi et al., 2010).

Problem of mineral deficiency and metabolic disease in all categories of dairy livestock have been reported by many Scientist due to lower content and low bioavailability of some essential macro and micro mineral in different 
feed stuffs. Regular feeding of mineral mixture supplement have reportedly improved milk yield in some parts of India (Tiwari et al., 2013). The present study was conducted to observe the effect of mineral mixture feeding on milk yield of buffalo over a period of 90 days.

\section{Material and Methods}

Twenty buffaloes ( 10 in treatment group, 10 in control group) were selected randomly from 5 villages of Western U.P. in Ghaziabad district (Muradnagar, Noorpur, Kanuoja, Kusalia, Badka) during the study period (October 2016 to December 2017).

All the animals were selected at a comparable stage of lactation i.e. within first month of lactation and were maintained under similar management conditions throughout the trial. Animals from treatment group were fed mineral mixture (Table A) at the rate of $60 \mathrm{~g} / \mathrm{animal} /$ day for a period of 3 months, whereas animals from control group were not fed supplemented, milk yield of these animal was recorded by their dairy farmer and these value were averaged daily milk yield, peak yield, total milk yield, milk fat percentage, SNF percentage, total milk solid and 90 days milk production (lit) was noted regularly in whole experiment period of 3 months. Forthightly analysis of milk sample was done to find out composition of the milk. The data recorded on various parameters were analyzed for statistical difference by analysis of variance (Snedecor and Cochran, 1989) and Duncan's multiple range test (Duncan, 1995).

On the basis of this, it is recommended that continuous feeding of mineral mixture bettered performance of milk yield in buffaloes.

\begin{tabular}{|lc|}
\hline \multicolumn{2}{|l|}{ Table A : Composition of mineral mixture (per 100 kg) } \\
\hline Source & Weight (in kg) \\
\hline Diacalcium phosphate & $55 \mathrm{~kg}$ \\
Calcium corbonate & $30 \mathrm{~kg}$ \\
Ferrous sulphate & $2 \mathrm{~kg}$ \\
Mangnesium sulphate & $10 \mathrm{~kg}$ \\
Copper sulphate & $0.5 \mathrm{~kg}$ \\
Manganese sulphate & $0.5 \mathrm{~kg}$ \\
Zinc sulphate & $0.5 \mathrm{~kg}$ \\
\hline
\end{tabular}

\section{Results ANd Discussion}

The results of the present study as well as relevant discussions have been presented under following sub heads:

\section{Milk yield parameter:}

The observation was recorded for milk yield and their composition and data presented in Table 1.

It was observed that average daily milk yield was found significant $(\mathrm{P}<0.05)$ higher in treatment group than the control group. Beside this, treated animals were produced significantly $(\mathrm{P}<0.05)$ higher total milk yield for 90 days than the control group. Noeek et al. (2006) has also found higher milk yield in mineral supplementation group of buffaloes. Average daily milk yield and total milk yield was found higher in treatment group over control group by 11.61 per cent and 15.00 per cent, respectively.

\begin{tabular}{|c|c|c|}
\hline Milk yield parameter & Treatment $(\mathrm{T})$ & Control (C) \\
\hline Average daily milk yield (lit) & $11.4 \pm 1.62$ & $9.6 \pm 1.42$ \\
\hline Peak milk yield (lit) & $12.37 \pm 0.17$ & $10.77 \pm 0.30$ \\
\hline Time laps to reach peak yield (day) & $31.2 \pm 1.12$ & $23.5 \pm 1.25$ \\
\hline Total milk yield for 90 day (lit) & $980 \pm 0.92$ & $878 \pm 1.25$ \\
\hline Average milk fat $\%$ & $7.84 \pm 0.37$ & $7.02 \pm 0.34$ \\
\hline Average milk SNF \% & $9.59 \pm 0.10$ & $9.24 \pm 0.78$ \\
\hline Total solid in milk & $18.02 \pm 0.17$ & $17.57 \pm 0.18$ \\
\hline
\end{tabular}

Singh et al. (2016) also reported same result of improved milk production in mineral fed buffaloes. The recorded peak milk production in treatment group was also found significantly $(\mathrm{p}<0.05)$ higher in treatment group. However, time laps to achieve peak production was found non-significant higher in treatment group. It mean buffalo fed with mineral mixture was getting more time in her peak production but these buffaloes were found more persist in nature. The treatment group buffaloes were able to hold per peak yield for longer duration than the control group. Result indicating that feeding of mineral mixture could improve milk production potential of buffaloes due to having impact on the milk production cells in the udder. Their micro and macro element contribute in the working of memory cell to enhance their production. These finding is in full agreement with Rohilla and Bohra (2007) observation.

Average percentage of milk fat was found nonsignificantly higher in treatment group $(7.84 \%)$ than the control group $(7.02 \%)$. The percentage SNF and total solid of milk (TS) was followed the same trend as the parameters were found non-significantly higher in mineral fed group than the control group. These finding was comparable with result obtained by Verma et al. (2009). 


\section{Conclusion:}

It could be recommended that supplementation of mineral mixture in milking buffaloes improve their health and production potential, so with its supplementation farmer can earn more profit from their buffaloes.

\section{Literature Cited}

Bhannderi, B.M., Garg, M.R. and Sherasia, P.L. (2014). Mineral status of feeds, fodders and dairy animals in Jalgaon district of Maharastra state. Sch. J. Agric. Vet Sci., 1(4A): 222-226.

Duncan, D.B. (1995). Multiple range and multiple "F", Tests. Biometrics, 11 : 1-42.

Goff, J.P. and Horst, R.L. (1997). Effect of the addition of potassium or sodium, but not calcium to prepartum ration on milk fever in dairy cows. J. Dairy Sci., 80: 176-186.

Noeek, J.E., Socha, M.T. and Tomlinson, D.J. (2006). The effect of trace mineral fortification level and source on performance of dairy cattle. J. Dairy Sci., 89(7): 2679-2693.

Rohilla, P.P. and Bohra, H.C. (2007). Effect of nutrimix feeding on milk yield of ewe and growth of lambs. Indian Vet. J., 84 : 1273-1275.

Singh, S., Chhabra, S., Singh, C., Randhawa, S.S. and Gupta, D.K. (2016). Effect of area specific mineral mixture feeding on milk yield and composition of dairy animals of central zone of Punjab. Internat. J. Livestock Res., 6(3): 62-65.

Sirohi, S.K., Walli, T.K. and Mohanta, R.K. (2010). Supplementation effect of bypass fat on production performance of lactating crossbreed cows. Indian J. Anim. Sci., 80 : 733-736.

Snedecor, G.W. and Cochran, W.G. (1989). Statistical methods. $8^{\text {th }} \mathrm{Ed}$. The Iowa State University Press, Ames. Iowa.

Tiwari, R., Sharma, M.C. and Singh, B.P. (2013). Awareness and impact of area speciic mineral mixture technology in field situation. Indian J. Anim. Sci., 83 (4):435-437.

Verma, R.K., Praveen Kumar, Adil, A. and Arya, G.K. (2009). Effect of feed supplement on milk production, fat \% total serum protein and minerals in lactating buffalo. Vet. World, 2(5): 193194. 